\title{
Preservation and Rendition of Computer Data in Slovak Criminal Procedure Code
}

\author{
Ivana Rabinská \\ Faculty of Law, Palacký University Olomouc, Czech Republic \\ ivana.rabinska@upol.cz
}

RABINSKÁ, Ivana. Preservation and Rendition of Computer Data in Slovak Criminal Procedure Code. International and Comparative Law Review, 2019, vol. 19, no. 2, pp. 285-299. DOI: 10.2478/iclr-2019-0025.

\begin{abstract}
Summary: The goal of this article is to analyse the Slovak legislation of preservation and rendition of computer data in accordance with section 90 of the Criminal Procedure Code, which was implemented in the Slovak legal order under the Convention on Cybercrime, Budapest, 23. 11. 2001. In particular, article 16 of the Convention on Cybercrime obliges the member states to adopt necessary legislative and other measures as may be necessary to enable its competent authorities to order or similarly obtain the expeditious preservation of specified computer data, including traffic data, that has been stored by means of a computer system, in particular where there are grounds to believe that the computer data is particularly vulnerable to loss or modify. In addition, the article examines the effects of the legislation adopted in practice, including the correlation problems that the legislator has not deal with and also brings up-to-date results of the fight against cybercrime.
\end{abstract}

Keywords: Convention on Cybercrime, crimes committed via the Internet and other computer network, infringements of copyright, computer-related fraud, child pornography and violations of network security, computer data, Slovak legal order, legislative and regulatory measures, computer system, traffic data.

\section{Introduction}

Computers and the Internet have become a common part of human life, through which we provide daily work, personal and social needs. Unfortunately, this trend brings negatives in the form of committing criminal activities using computer technology, whether it be fraudulent acts, hacking, blagging, moral crimes, hate crimes or copyright infringement etc. It is an environment that is anonymous, the offender is usually not at the scene of the crime, and the victim is ashamed that they were bumped. ${ }^{1}$ The data and information stored on the

1 For general analyses see: CARR, Indira. Computer crime. Routledge, 2017; IGLEZAKIS, Ioannis. The Legal Regulation of Cyber Attacks. Wolters Kluwer, 2016; CARR, Indira, WILLIAMS, Katherine, S. Computers and law. Intellect Books, 1994; or VALUCH, Jozef; GÁBRIŠ Tomáš; HAMULÁK, Ondrej. Cyber attacks, information attacks, and postmodern warfare. Baltic Journal of Law \& Politics, 2017, vol. 10, no. 1, pp. 63-89. 
information carriers can be easily manipulated including their complete deletion so cybercrime is so hard to detect.

In the year of 2001, a Convention on cybercrime was adopted by the Committee of Ministers of the Council of Europe (hereinafter referred to as Convention), to „deter action directed against the confidentiality, integrity and availability of computer systems, networks and computer data as well as the misuse of such systems, networks and data by providing for the criminalisation of such conduct, as described in this Convention“" 2

It obliges member states to criminalise such behaviour and to adopt powers sufficient to effectively deter such offences, to facilitate the detection, investigation and prosecution of such offences at national and international level, and to establish mechanisms for swift and reliable international cooperation.

The Convention contains substantive (chapter II, Part 1) and procedural provisions (chapter II, Part 2), defines the basic concepts (Chapter I, article 1) and governs international cooperation (chapter III), i.e. constitutes a comprehensive tool to deter computer crime. Its adoption was preceded by two recommendations of the Committee of Ministers of the Council of Europe, the first ${ }^{3}$ of 1989 on computer-related crime, establishing guidelines for national legislators on the definition of certain computer crimes, and the other ${ }^{4}$ in 1995 on problems of criminal procedural law related to information technology. The Convention was signed by all states of the Council of Europe except the Russian Federation. Given its importance, the Convention is open to signature by non-member states of the Council of Europe (19 non-member states have so far ratified) $)^{5}$. The Convention was adopted by an additional protocol concerning the criminalisation of acts of a racist and xenophobic nature committed through computer systems (hereinafter referred to as the Protocol) ${ }^{6}$. The purpose of this Protocol is to supplement the provisions of the Convention as regards the criminalisation of acts of a racist and xenophobic nature committed through computer systems.

2 Convention on Cybercrime as of 23 November 2001, treaty no. 185.

3 Recommendation No. R (89) 9 of the Committee of Ministers to memeber states concerning on computer-related crime (Adopted by the Committee of Ministers on 13 September 1989, at the 428th meeting of the Ministers'Deputies).

4 Recommendation No. R (95) 13 of the Committee of Ministers to memeber states concerning problems of criminal procedural law connected with information technology (Adopted by the Committee of Ministers on 11 September 1995, at the 543rd meeting of the Ministers'Deputies).

5 In total 63 states acceded to the Convetion on Cybercrime, incl. USA, Canada, Japan, Israel, Australia [online]. Chart of signatures and ratifications of Treaty 185. [cit. 20 September 2019]. Available at: https://www.coe.int/en/web/conventions/full-list/-/conventions/ treaty/185/signatures?p_auth=C9U026R5.

6 See Additional Protocol to the Convention on Cybercrime, concerning the criminalisation of acts of a racist and xenophobic nature committed through computer systems, Strasbourg, 28 January 2003, treaty no. 189: Chapter 1 - Common provisions, Article 1 - Purpose. 
For law enforcement authorities, the detection of cyber crimes due to the anonymity of the environment and the cross-border dimension is very intricate and without adequate legal means, evidence of this crime cannot be obtained. ${ }^{7}$ At the same time, fundamental human rights must be adequately protected in order to avoid conflicts between legal instruments of the Criminal Procedure Code and guaranteed human rights and freedoms of individuals.

\section{Preservation and rendition of computer data under section 90 of the Criminal Procedure Code}

The Slovak legislators who have also ratified this Convention (12 December 2007, effective since 1 May 2008) have in their Criminal Procedure Code ${ }^{8}$ (hereinafter referred to as the c.p.c.) a provision enabling the regulation of accelerated retention of data, disabling access to this data or the deletion of such data (see section 90 Preservation and rendition of computer data). The purpose of this institute is to detect and investigate criminal offences committed via the Internet. This provision is found in the fourth title of c.p.c., called securing people and things. The application of this institute is decided by the Presiding judge and before the prosecution or preliminary proceedings by the Prosecutor (section 90 par 1 c.p.c.).

Basically, according to section 90 c.p.c., two types of orders can be issued. Firstly, the order for the preservation of computer data and the order for the rendition of computer data, the content of which is to: (a) keeping and maintaining the integrity of the data, (b) enabling and retaining copies of the data, (c) preventing access to the data, $(\mathrm{d})$ removing data from the computer (e) releasing the data for the purpose of criminal proceedings. The order is to be justified by factual circumstances, but the scope of which is not defined further. The order is a sui generis decision, it must have a written form and no appeal is admissible against it. And as in the Czech Republic there are no delimitation of offences for which this is possible. Of course, the most significant in terms of interference with the guaranteed right to privacy is the obligation to rendition data for the purposes of criminal proceedings. In this the Slovak legislature went beyond the border of article 16 of the Convention, because it required only the swift retention of data for future exunder-law enforcement authorities.

The order is directed against the person in whose possession or under whose control the data are located or against the service provider - eg. the webhost operator (section 90 par 1 c.p.c.). They may also be required to keep confidential the measures referred to in the order (section 90 par 4 c.p.c.), logically so as not

7 See further: BALKIN, J., GRIMMELMANN, James, KATZ, Eddan, KOZLOVSKI, Nimrod, WAGMAN, Shlomit, ZARSKY, Tal. Cybercrime: Digital Cops in a Networked Environment. NYU Press, 2007.

8 Act no. 301/2005 Coll., Criminal Procedure Code, as amended by later legal regulations. 
to frustrated the evidence. This specially modified duty of secrecy is directed towards the future?

The information which is the subject of the order is to be issued to the presiding judge or to the prosecutor who issued the order or to another person who is in the order referred to (typically a policeman who is in the case of an investigation - section 90 par 5 c.p.c.). The order may cover all types of data stored in computerized systems or on data carriers where they are relevant to criminal proceedings, but must also be such data that can be made accessible to the prosecuting and adjudicating bodies and specified in an individual order, which is issued for a limited period of time. In the sense of article 16 of the Convention is the preservation of stored data that has already been collected - data preservation. In particular, it will be „data with a short storage period, especially if, according to trade policy, it is deleted after a certain time or is deleted whenever new data is uploaded to the respective medium. This may be due to the nature of the stored data manager or to a lack of secure storage. In the order to retain data and maintain it in the entirety referred to in paragraph $1 \mathrm{a}$ ) and to prevent access to the data referred to in paragraph $1 \mathrm{c}$ ) the period for which it is to be followed shall be determined. "10 The validity period of a order can take up to 90 days. If the purpose of the order is not reached within a maximum period of 90 days, a new order must be issued (section 90 par 2 c.p.c.). If according to the conclusion of the presiding judge or the prosecutor, further retention of data is no longer necessary for the purposes of criminal proceedings, they shall issue an order to cancel data retention. This provision appears to be redundant in the light of the principle of officiality. ${ }^{11}$

Computer data are in accordance with section 90 of the c.p.c. any representation of facts, information or concepts in a form suitable for processing in a computer system, including a program allowing the performance of a function to be ordered by a computer system. As in the Czech legislation "freezing" of data under section 7b parl of the Criminal Procedure $\operatorname{Code}^{12}$, is the purpose of keeping the data already stored - data preservation, therefore this provision does not apply to the blanket retention of data to be stored in the future or which are currently transmitted - data retention. It is necessary to look out for the poorly formulated order (e.g. "to keep all computer data obtained in the future and to maintain confidentiality"). There may be a serious interference with the rights of the investigated without the court's procedural control. Such an order would

9 For more info see below regarding to computer data.

10 See explanatory report available at: http://www.psp.cz/sqw/text/tiskt. sqw? $\mathrm{O}=8 \& \mathrm{CT}=79 \& \mathrm{CT} 1=0$.

11 ABELOVSKÝ, Tomáš: Zaistenie elektronického dôkazu vo svetle rekodifikácie trestného poriadku. Revue pro právo a technologie. 2015. vol. 6. no. 11. p. 41.

12 Act no. 141/1961 Coll., Criminal Procedure Code, as amended by later legal regulations. 
de facto replace the eavesdropping (e.g. streaming calls, future electronic mail, etc. $)^{13}$

Traffic data is any computer data related to communication through a computer system, generated by the computer system that formed part of the communication chain, indicating the origin, destination, route, time, date, volume, durativ, size or type of underlying servis.

A computer system, as defined in section 90 c.p.c., means a PC as a functional unit that can perform computations of all numerical arithmetic and logical operations without human intervention and according to a particular program and which has hardware (harddware) including such as accessories (printer, mouse, scanner, modem) and software, which consists of information-processing programs. ${ }^{14}$ Therefore, the computer system cannot be identified with a computer network (e.g. the Internet) and the data stored in the computer system (which can be obtained in accordance with section 90 c.p.c.) cannot be identified with data transmitted through the computer system to the computer network, which at the same time remained "hang" in the computer network on a particular server (i.e. basically they are stored not in the computer system, but in the computer network on the email server).

From the logic of the matter, this provision will apply not only to data stored in the computer system, but also to data stored on other media, the so-called information carriers. It is „any data carrier in information technology, ie material into or on which data can be recorded („written”) and from which data can be retrieved („read”) - eg hard disk (so called „HDD”) or hard disk), RAM (memory), floppy disk, CD-R, CD-RW, DVD-R, DVD + R, DVD-RW, DVD + RW, Blu-Ray, USB key, mobile phone. Sound or cinematographic recordings or video recordings, even if recorded on a magnetic tape, cannot be considered as a medium of information. ${ }^{15}$ This is an older definition, so over time, and in particular the rapid evolution of computer technology, some carriers are no longer used and have been replaced by new ones. According to other authors „magnetic tapes (typically used for backing up disk arrays), memory cards (generally used in electronics - in digital cameras, laptops, mobile phones, players, etc.) can be considered as information carriers; types are eg SD, mini SD, micro SD, SDHC, $\mathrm{xD}, \mathrm{SDXC}$, MemoryStick, etc.). In the view of the author however, we should identify all media capable of storing primarily digital information as information carriers; including tablets, smartphones, e-book readers, and apparently we could include GPS, digital audio and video recorders (iPod), etc." ${ }^{16}$

13 ABELOVSKÝ, Tomáš: Zaistenie elektronického dôkazu vo svetle rekodifikácie trestného poriadku. Revue pro právo a technologie. 2015. vol. 6. no. 11. p. 42.

14 KLIMEK, Libor a kol. Počítačová kriminalita v európských súvislostiach. Wolters Kluwer, Bratislava 2016, p. 153.

15 Explanatory report takes over definition from Commentary: ŠÁMAL, Pavel a kol. Trestní zákoník II. Komentár. 2. edition, Praha: C. H. Beck, 2012, p. 2308.

16 SMEJKAL, Vladimír. Kybernetická kriminalita. Plzeň: Aleš Čeněk, 2015. p. 41. 
In the sense of the above definition, we can also consider the so-called cloud storage as information carrier. ${ }^{17}$ Cloud storage makes it easy to back up data, share it among different users, and easily access files from multiple devices (laptop, tablet, phone, etc.). Access depends on your Internet connection. ${ }^{18}$ This service allows you to store your data by transferring it over the Internet or other network to a third-party managed off-site storage system (eg mailbox, internet diary, etc.). ${ }^{19}$ The disadvantage of this service is both the security risk of data, where there is a risk of unauthorized access to someone else and also violation of privacy, because some providers reserve the right to access this data!

A protocol is written on the procedural act under section 90 c.p.c., which is then an important basis for checking the legality of such an intervention. The protocol must contain a sufficiently precise description of the case, withdrawn items, cases (data carrier) or computer data (e.g. name and specification of secured files or partitions of discs) which will enable them to be identified. A person who has rendered a data carrier or computer data or has been withdrawal the data cerrier or computer data, or from which the data carrier or computer data has been recepted, shall issue the authority which carried out the act, without delay, with written confirmation of the receipt of the case or of computer data or a copy of the protocol.

\section{Provision 90 of the Criminal Procedure Code v. provision 116 of the Criminal Procedure Code}

Currently prosecuting and adjudicating bodies cannot request content data from a telecommunications service provider without the consent of a court. Canceled clause of section 116 par 4 c.p.c. „Identification and communication of data on telecommunications operations" has related to the content and traffic data transmitted through the computerised system. In accordance with the procedure referred in this paragraph, information on the communicati on of any telecommunications user, the end of the call and the calling number (list of incoming and outgoing calls), the type of service used (telephone call, SMS), date, time, duration of the communication and place of connection (marking of cells-identity of the radio equipment of the mobile network from which the call

17 See more Standpoint of criminal board of Supreme Court of 25 June 2015, sp. zn. Tpjn 306/2014 k otázce výkladu pojmu „jiné prostory, v nichž advokát vykonává advokacii“ ( $\$ 85 \mathrm{~b}$ odst. 1 tr. ř.) a $\mathrm{k}$ otázce, zda o návrhu ve smyslu $\$ 85 \mathrm{~b}$ odst. 3 tr. ř. má být vždy rozhodováno formou usnesení, nebo zda přichází v úvahu i jiná forma „rozhodnuti“ a za jakých podmínek: „......listinou ve smyslu $\$ 85 \mathrm{~b}$ tr. ř. se rozumí nejen písemnosti, popřr. jejich části, ale i nosiče dat. Cloudové úložiště bezesporu má povahu nosiče dat, v němž mohou být v elektronické podobě uložena veškerá data spojená $s$ výkonem advokacie. Je tedy nutné považovat je za listinu ve smyslu $₫ 85 \mathrm{~b}$ odst. 12 tr. r..“

18 Tajemství cloudu odhaleno. [online]. Cloudforc.cz. 26. 9. 2006. [cit. 25 August 2019]. Available on <http://www.cloudforce.cz/tajemstvi-cloudu-odhaleno/>.

19 Co je cloudové úložištěe? [online]. azure.microsoft.com. [cit. 25 August 2019]. Available on $<$ https://azure.microsoft.com/cs-cz/overview/what-is-cloud-storage/>. 
started or ended via the mobile terminal device) could be obtained. The plenary of the Slovak Constitutional Court proclaimed that among other things section 116 c.p.c. does not respect the constitutively guaranteed rights of the inhabitants for privacy and protection of personal data. ${ }^{20}$ In addition to section 116 of the c.p.c., the provisions of section 58 par 5 to 7 and section 63 par 6 of act no. 351/2011, collection of laws of the Slovak Republic, electronic communications, which have so far ordered operators to monitor the communication of their users and also the provisions of section 76 par 3 of act no. 171/1993 of collection of laws of the Slovak Republic, police corps, which allowed them to be expose. When comparing the implementation of the canceled provisions of section 116 c.p.c. and section 90 c.p.c. it is interesting that the order to secure and notify the data on the telecommunications operations carried out in writing by the presiding judge and before the commencement of the prosecution or preliminary proceedings of the judge for preparatory proceedings on a proposal from the prosecutor, which had to be justified by the facts. While the order under section 90 par 1c.p.c. may also issue in preliminary proceedings the prosecutor.

A computer network is the interconnection of computers so that they can communicate with each other, share data and information. The Internet is a kind of global system of interconnected computer networks. However, it is not a thing in the legal sense (section 130 par 2 of the Penal Code ${ }^{21}$ ). According to Smejkal it is an information and communication system consisting of various entities and objects of legal relations. ${ }^{22}$

Likewise email communication or SMS communication (incl. applications such as WhatsApp) is not a thing until it is stored or downloaded on some technical medium (mobile phone, computer, CD, DVD, USB, memory card, etc). So until such communication is withdrawn and is still part of the mailbox on the Internet it is not possible to consider it as a piece of information that would be on the data carrier eg. computer's hard disk and cannot be secured e.g. in the search of premises. To ensure the content of such communication can be through the provisions of section 116 par 6 c.p.c. Similarly it will be treated in the case of the so-called Cloud computing where data is stored on servers on the Internet, when the cloud provider does not have to reside in the territory of the Slovak Republic but anywhere in the world.

The essence of the order under section 116 par 6 c.p.c. is a reasoned injunction to the prosecuting and adjudicating bodies, in purpose to ensure the content relevant to the criminal proceedings (i.e. the conversation of the offender, the annexes in the form of invoices or contracts, etc.) to enter into a specific e-mail

20 Judgment of Constitutional Court of the Slovak Republic of 29 April 2015, file no. PL. ÚS $10 / 2014$.

21 Act no. 300/2005 of collection of laws of the Slovak Republic, Penal Code, as amended by later legal regulations.

22 SMEJKAL, Vladimír. Kybernetická kriminalita. Plzeň: Aleš Čeněk, 2015. p. 58. 
box of course when the conditions specified in section 116 par 1 c.p.c., therefore on suspicion of committing the offence referred to therein. Thus the application of the order under section 116 par 6 c.p.c. it is possible to obtain data transmitted via computer system via computer network or data which remain stored within the computer network on the server of the email service provider. The operator may be required within the meaning of section 116 par 2 c.p.c. only traffic data i.e. the IP address, the password in the e-mail box, not the contents of the clipboard.

By contrast, a computer system within the meaning of section 90 c.p.c. is a $\mathrm{PC}$ as a functional unit, something different from the computer network through which data is transferred. The data is stored in the computer system and in criminal proceedings, it can be achieved through section 90 c.p.c. Thus everything that is stored on any data carrier (mobile phone, computer, DVD, etc.) is a thing within the meaning of section 130 par 2 of the Penal Code and can be ensured e.g. search of premises or other securing institutes.

So the provisions of section 90 c.p.c. can not be applied to the cases described above. It is not possible to order the suspect to keep the data in his mailbox unchanged, because there are no legal instruments in fact to ascertain whether compliance with this order has been complied with when the prosecuting and adjudicating bodls do not have an email clipboard access.

The provisions of section 90 c.p.c. may not be used in the provision of the contents of mailboxes since the concerned provision applies only to data stored on servers of Internet service providers. The content of email communications located in email clipboard is not an information to which the email service operator should have legal access. Szabová disagrees with this view and analyzes Google's permission in relation to its Gmail product to store the contents of the mailboxes. According to Google's terms and conditions specifically in the section on requests for user data, is modified procedural route "through which it may be forced to rendition the content of such information, such as the content of email communications, documents, videos or photos stored by a Google account user. This procedural route is linked to the institute applied in the U.S. legal environment - with the institute in the form of the inspection order which is modified by the federal law on Personal Data Protection (Electronic Communications Privacy Act) but for the purpose of demonstrating the above presumption that Google imposes an email User communication and has legal access to it, this information appears more than sufficient. ${ }^{\text {"23 }}$

23 SZABOVÁ, Eva. Vybrané praktické problémy využitia prostreidkov na zabezpečovanie informácií v prípravnom konaní. In ŠČERBA, Filip, ŠČERBOVÁ, Veronika (eds). Olomoucké právnické dny 2018. Sborník z XII. ročníku mezinárodní vědecké konference Olomoucké právnické dny (Sekce trestního práva) pořádané ve dnech 24.-25. 5.2018 Právnickou fakultou Univerzity Palackého v Olomouci. 1. vydání Olomouc: Iuridicum Olomoucense, o.p.s., 2018, s. 102-122. 
In this context, it is also appropriate to mention the decision of the Supreme Court of the Slovak Republic whether or not the provision of a order for securing and notification is necessary to secure information in a issued, withdrawn or secured mobile phone or other technical device. Data on telecommunications in accordance with section 116 c.p.c. in his opinion, there is no need for any further order, for such a procedure would be irrational and duplicative, and would contradict the economy and effectiveness of criminal proceedings. ${ }^{24}$

\section{Conflicts with the right to privacy}

The legislation of this securing instrument interferes with the right to privacy and the protection of personal data. The Constitution of the Slovak Republic ${ }^{25}$, in art. 19 par 3 sets out three parts of the constitutional right to the protection of personal data, namely the right to protection against their 1 . collecting, 2 . publication or 3. abuse. While the first two are instantiated directly in the Constitution, the misuse of the data of the person relates to any further treatment of them (different from their collection or publication) if it can be characterized as an abuse. ${ }^{26}$

Whenever a public authority is to intervene in the rights or legitimate interests of an individual, it is necessary to examine the lawful constraints of such an intervention, which should be entirely exceptional if the purpose cannot be otherwise achieved and should be subject to scrutiny.

The judgment of the Constitutional Court of the Slovak Republic ${ }^{27}$ shows how the evaluated state interference in the right to privacy which is directly related to that securing institute is to be established since the subject of a means of protection under section 90 c.p.c are electronic data of different character (private, working, publicly shared, etc.) stored on one computer/repository. In accordance with the case-law of the European Court of Human Rights different aspects of state interference are explored. First it seeks to ascertain whether the factual situation ratione materiae is part of the right to privacy and consequently the intervention of the state is assessed from the point of view of its legality (whether it was carried out on the basis of the applicable law), legitimacy (intervention corresponds to the aim of protection national security or health or morality protection, etc.) and proportionality (balancing the relationship between individuals right to privacy and the choice of means of achieving

24 Resolution of the Supreme court of the Slovak Republic of 23 March 2017, criminal judicial file no. 5 Tdo $7 / 2017$.

25 Act no. 460/1992 Coll., Constitution of the Slovak Republic, as amended by later legal regulations.

26 Judgment of Constitutional Court of the Slovak Republic of 29 November 1995, criminal judicial file no. I. ÚS 33/95.

27 Judgment of Constitutional Court of the Slovak Republic of 25 August 2010, criminal judicial file no. III. ÚS 68/2010. 
the objective). The Constitutional Court in this finding, among others said that: "The state's interest in the protection against criminal offences establishing the legitimacy of interference with the right to privacy in the implementation of certain institutes under the fourth title of the first part of the Criminal procedure (called "Detention of persons and seizure of property") must be put into balance with the severity of the intervention to that right. This means choosing to take action as temperer as possible, which is at the same time capable of ensuring the achievement of the objective pursued, for example by prioritising the act of preservation and rendition of computer data before the institute of delivery and/ or withdrawal of the thing. Otherwise, the non-proportional procedure of the acting authority shall be an infringement of the right to privacy and fair process. "The legislation reflects these requirements and, to achieve the specific objective of obtaining computer data relevant for clarifying criminal activities, determines the means which guarantees the required proportionality, i.e. the act of the preservation and rendition of computer data according to section 90 c.p.c. According to the Constitutional Court of the Slovak Republic the realization of the institute of the preservation and rendition of computer data according to section 90 c.p.c. less intense interference with the right to privacy than eg. rendition of thing according to section 89-91 c.p.c. It allows third parties to apply a less intensive instrument of intervention (the rendition of specific computer data) prior to the rendition of a complete data carrier, which is a last resort solution. The scheme of realization of both securing institutes is different. The demand under section 89 par 3 c.p.c. to render the thing does not need the order or consent of the prosecutor, to withdraw the thing under section 91 par 1 c.p.c. suffice the order of the police authority, issued after the previous voice of the prosecutor, without the prior consent of the prosecutor only, if it was not possible to achieve the consent and the case does not bear the delay. In contrast to the realization of the act of preservation and rendition of computer data according to section 90 c.p.c. it is necessary to commend the prosecutor as the authority exercising supervision of observance of legality.

At transnational level the procedure under section 90 c.p.c. collides with article 8 of the Convention for the Protection of Human rights and fundamental freedoms. ${ }^{28}$ "The right to respect private life includes a guarantee of selfdetermination in the sense of the individual's fundamental decision-making. In other words the right to privacy also guarantees the right of an individual to decide whether or not the extent to which the facts and information of his

28 See more: VAN DEN HOVEN VAN GENDEREN, Robert. Privacy Limitation Clauses: Trojan Horses under the Disguise of Democracy. Wolters Kluwer, 2016 or GUTWIRTH, Serge, POULLET, Yves, DE HERT, Paul, LEENES, Ronald. Computers, Privacy and Data Protection: an Element of Choice. Sprienger Science + Business Media, 2011. 
personal privacy are to be disclosed to other entities. ${ }^{\text {“29, } 30}$ The fundamental right defined in this way may be combined with article 19 of the Constitution of the Slovak Republic abbreviated as the right to information self-determination. Even if private conduct takes place in public space - eg. on social networks, consent to the waiver of the right to privacy cannot be inferred. „This sphere can be entered under certain conditions, as there may be facts which may be subject to a legitimate public interest. The social sphere can thus be disturbed by proportional interventions by public authorities in order to protect the interests of the community. ${ }^{\text {"31 }}$

The European Court of Human Rights (ECHR) has extended the applicability of privacy rights within the meaning of art. 8 of the Convention on the Protection of Human rights and Fundamental Freedoms, as well as professional activities (e.g. correspondence with a lawyer ${ }^{32}$ ) and business activities ${ }^{33}$. Likewise, the concept of correspondence is widely interpreted. The protection of article 8 of the Convention for the Protection of Human rights and Fundamental Freedoms is primarily to protect an individual from arbitrary public intervention. The ECHR understands the notion of "dwelling" within the meaning of article 8 of the Convention for the Protection of Human rights and Fundamental Freedoms not only as a home, but also as an office, company headquarters, branches, vehicle, etc. The concept of correspondence relates both to the documents (in writing) and to the data stored in electronic form or to the list of websites visited by the employee, and the protection is accorded to telephone calls. In addition to the legality and legitimate aim of the breach in this confidential relationship the existence of procedural safeguards in order to ensure that the relationship is not distorted to an unreasonable degree is required by the national authorities of the ECHR to intervene in the right to privacy. ${ }^{34}$

29 Judgment of Constitutional Court of the Czech Republic of 22 March 2011, file no. Pl. ÚS $24 / 10$.

30 See more Judgment of Constitutional Court of the Czech Republic of 17 July 2007, file no. IV. ÚS 23/05.

31 Judgment of Constitutional Court of the Czech Republic of 17 July 2007, file no. IV. ÚS 23/05-2.

32 Campbell v. United Kingdom of 25 March 1992, Application no. 13590/88.

33 Klass and others v. Germany of 6 September 1978, Application no. 5029/71, Niemietz v. Germany of 16 December 1992, Application no. 13710/88.

34 See more Standpoint of criminal board of Supreme Court of 25 June 2015, no. Tpjn 306/2014 k otázce výkladu pojmu „jiné prostory, v nichž advokát vykonává advokacii“ ( $\$ 85 \mathrm{~b}$ odst. 1 tr. ř.) a $\mathrm{k}$ otázce, zda o návrhu ve smyslu $\$ 85 \mathrm{~b}$ odst. 3 tr. ř. má být vždy rozhodováno formou usnesení, nebo zda při chází v úvahu i jiná forma „rozhodnuti“" a za jakých podmínek: „.....listinou ve smyslu $₫ 85 \mathrm{~b}$ tr. ř. se rozumí nejen písemnosti, popr. jejich části, ale i nosiče dat. Cloudové úložiště bezesporu má povahu nosiče dat, v němž mohou být v elektronické podobě uložena veškerá data spojená $s$ výkonem advokacie. Je tedy nutné považovat je za listinu ve smyslu $\$ 85$ b odst. 12 tr. r..“ 


\section{Comparison with Czech legislation of preservation and rendition of computer data}

Czech legal regulation of „freezing“ data necessary for criminal trial is quite new institut (effective from 1 February 2019) so there are no experiences with this preliminary ruling. Prosecuting and adjudicating bodies have been using different measures of criminal law to achieve similar goal such as search of premises, rendition of a thing or seizure of a thing material for criminalproceedings.

By act no. 287/2018 Coll. was introduced into the Czech Criminal Procedure Code (hereinafter the c.c.p.c.) ${ }^{35}$, effective from 1 February 2019, inter alia, a new institute of the type of preliminary ruling, namely the expedited preservation of data stored in a computer system or on a data carrier for criminal trial purposes. According to the explanatory report the new legislation (section $7 \mathrm{~b}$ par. 1 of the c.c.p.c.) aims to „temporarily prevent the loss, alteration or destruction of data relevant to criminal proceedings (for evidence) in order to preserve the integrity of such data, and until such time as an order to disclose the content of these data to prosecuting and adjudicating bodies is given by the c.c.p.c. provided for in the procedure". ${ }^{36}$

Data must be specified in an individual order, which is issued for a limited period of time. Pursuant to Article 16 of the Convention ${ }^{37}$, it is the preservation of stored data that has already been collected - data preservation, thus this provision does not apply to future data or data which are currently being transmitted - data retention. No subsequent order to cancel retention of data is needed as it is set in slovak legislation.

According to section $7 \mathrm{~b}$ par. 2 c.c.p.c. a person may be ordered to hold or control data stored in a computer system or on a data carrier to prevent other persons from having access to such data if this is necessary to prevent the continuation or recurrence of the crime. According to the Minister of the Interior „the purpose of this institute is to provide for an explicit procedure which, in the case of committing crimes such as offering child pornography on a website, fraudulent e-shops, illegal arms sales or computer virus preventing access to such data." ${ }^{38}$

The order is delivered to the person to whom it is directed, ie to the person who holds the data or has it under its control (section $7 b$ par. 5 c.c.p.c.). It may also be ordered to take the necessary measures to prevent disclosure of the data

35 Act no. 141/1961 Coll., Criminal procedure code, as amended by later legal regulations.

36 See explanatory report available at: http://www.psp.cz/sqw/text/tiskt. sqw? $\mathrm{O}=8 \& \mathrm{CT}=79 \& \mathrm{CT} 1=0$.

37 Convention on Cybercrime as of 23 November 2001, treaty no. 185.

38 Report on 27 meeting of Chamber of Deputies of the Parliament of the Czech republic [online]. psp.cz. 14 March 2019. Available at: http://www.psp.cz/eknih/2017ps/ stenprot/027schuz/s027244.htm. 
retention order. The prosecuting and adjudicating bodies logically take this step because it is an institute of a preliminary nature and such data processing is not public.

Data retention is a preliminary ruling that provides prosecuting bodies necessary time to subsequently secure data, so it should be kept secret so that others do not attempt to alter or destroy the data.

With regard to main concepts of law such as data, computer system, data carriers, retention of data, cloud storage, czech and slovak legislations are identical.

\section{Conclusion}

By implementing article 16 of the Convention on Cybercrime the Slovak Republic has observed its obligations as a member state of the European Union. Thus legal instruments to detect cybercrime through the acquisition of electronic evidence from technical devices exist but the efforts of law enforcement agencies and national authorities are significantly limited by the efforts of the European Union on enhancing privacy including protection of private communications as well as the unwillingness of co-operating companies producing technical equipment as well as the IT skills/abilities of criminals and on the other hand the staffing underpower of these experts in the investigation teams of police. In investigating this criminal activity care must be taken to ensure that the principle of proportionality is respected and that the instruments provided by the criminal prosecuting and adjudicating bodiesare appropriately selected. A national network was established in 2017 to exchange practical knowledge concerning cybercrime, application problems in dealing with these crimes and to support cooperation with the Cybercrime Department of the Police Headquarters to fight cybercrime. According to general prosecutor's report ${ }^{39}$ it can be noted that in recent years there has been no significant increase in cybercrime but this can be mainly due to the latent nature of this kind of criminal activity. In practice indirect cybercrime prevares where the computer system serves as a means of committing crimes previously committed in another environment (e.g. fraud or theft). Property offence with the use of computer systems is still the most common criminal activity because its detection is very demanding in terms of detecting and convicting criminals who are committing criminal activities via the Internet, thus from foreign countries, which in effect also affects the acquisition of evidence, also with regard to the passage of time in relation to the preservation of essential information. Criminals are aware that international

39 Report of the Prosecutor General of the Slovak Republic on the Activities of the Public Prosecutor's Office in 2018 [online]. Správa generálneho prokurátora Slovenskej republiky o činnosti prokuratúry v roku 2018 a poznatkoch prokuratúry o stave zákonnosti v Slovenskej republike. [cit. 20th October 2019]. Available on: https://www.genpro.gov.sk/ spravy-o-cinnosti/sprava-generalneho-prokuratora-slovenskej-republiky-o-cinnostiprokuratury-v-roku-2018-a-po-3a45.html. 
cooperation in the field of evidence in these matters is challenging, slow and inefficient. So a significant part of the criminal proceedings are closed by suspension of criminal prosecution. The reason for this is most often the fact that a publicly available IP address belongs to multiple people. Also, the time gap between the committed crime and the first criminal acts plays a significant role.

International legal aid was implemented in criminal matters relating to property crime, Fraud, legalisation of income from crime, dissemination of child pornography, extortion and infringement of copyright.

The challenge for prosecuting and adjudicating bodiesis according to the report the issue of e-filing, electronic data storage, encryption and its impact on criminal proceedings.

\section{References}

ABELOVSKÝ, Tomáš. Zaistenie elektronického dôkazu vo svetle rekodifikácie trestného poriadku. Revue pro právo a technologie. 2015. vol. 6. no. 11.

Act no. 141/1961 Coll., Criminal Procedure Code, as amended by later legal regulations. Act no. 300/2005 Coll., Penal Code, as amended by later legal regulations.

Act no. 301/2005 Coll., Criminal Procedure Code, as amended by later legal regulations. Act no. 460/1992 Coll., Constitution of the Slovak republic, as amended by later legal regulations.

Additional Protocol to the Convention on Cybercrime, concerning the criminalisation of acts of a racist and xenophobic nature committed through computer systems, Strasbourg, 28 January 2003, treaty no. 189: Chapter 1 - Common provisions, Article 1 - Purpose.

BALKIN, J., GRIMMELMANN, James, KATZ, Eddan, KOZLOVSKI, Nimrod, WAGMAN, Shlomit, ZARSKY, Tal. Cybercrime: Digital Cops in a Networked Environment. NYU Press, 2007.

Campbell v. United Kingdom of 25 March 1992, Application no. 13590/88.

CARR, Indira, WILLIAMS, Katherine, S. Computers and law. Intellect Books, 1994.

CARR, Indira. Computer crime. Routledge, 2017.

Co je cloudové úložiště? [online]. azure.microsoft.com. [cit. 25 August 2019]. Available on $<$ https://azure.microsoft.com/cs-cz/overview/what-is-cloud-storage/>.

Convention on Cybercrime as of 23 November 2001, treaty no. 185.

GUTWIRTH, Serge, POULLET, Yves, DE HERT, Paul, LEENES, Ronald. Computers, Privacy and Data Protection: an Element of Choice. Sprienger Science + Business Media, 2011.

IGLEZAKIS, Ioannis. The Legal Regulation of Cyber Attacks. Wolters Kluwer, 2016.

Judgment of Constitutional Court CZ of 17 July 2007, no. IV. ÚS 23/05-2.

Judgment of Constitutional Court SR of 22 March 2011, no. Pl. ÚS 24/10.

Judgment of Constitutional Court SR of 29 April 2015, No. PL. ÚS 10/2014.

Judgment of Constitutional Court SR of 29 November 1995, no. I. ÚS 33/95.

Klass and others v. Germany of 6 September 1978, Application no. 5029/71, Niemietz v.

Germany of 16 December 1992, Application no. 13710/88.

KLIMEK, Libor a kol. Počitačová kriminalita v európských súvislostiach. Wolters Kluwer, Bratislava 2016, p. 153. 
Recommendation No. R (89) 9 of the Committee of Ministers to memeber states concerning on computer-related crime (Adopted by the Committee of Ministers on 13 September 1989, at the 428th meeting of the Ministers'Deputies).

Recommendation No. R (95) 13 of the Committee of Ministers to memeber states concerning problems of criminal procedural law connected with information technology (Adopted by the Committee of Ministers on 11 September 1995, at the 543rd meeting of the Ministers'Deputies).

Resolution of the Supreme court SR of 23 March 2017, no. 5 Tdo 7/2017.

ŠÁMAL, Pavel a kol. Trestní zákoník II. Komentář. 2. edition, Praha: C. H. Beck, 2012.

See more Judgment of Constitutional Court CZ of 17 July 2007, no. IV. ÚS 23/05.

SMEJKAL, Vladimír. Kybernetická kriminalita. Plzeň: Aleš Čeněk, 2015.

Standpoint of criminal board of Supreme Court of 25. 6. 2015, sp. zn. Tpjn 306/2014 k otázce výkladu pojmu ,jiné prostory, v nichž advokát vykonává advokacii“ (section $85 \mathrm{~b}$ odst. 1 tr. ř.) a $\mathrm{k}$ otázce, zda o návrhu ve smyslu section $85 \mathrm{~b}$ odst. 3 tr. ř. má být vždy rozhodováno formou usnesení, nebo zda přichází v úvahu i jiná forma „rozhodnuti“ a za jakých podmínek: „......listinou ve smyslu section $85 \mathrm{~b}$ tr. ř. se rozumí nejen písemnosti, popř. jejich části, ale i nosiče dat. Cloudové úložiště bezesporu má povahu nosiče dat, $\mathrm{v}$ němž mohou být v elektronické podobě uložena veškerá data spojená $s$ výkonem advokacie. Je tedy nutné považovat je za listinu ve smyslu section $85 \mathrm{~b}$ odst. 12 tr. r.."

SZABOVÁ, Eva. Vybrané praktické problémy využitia prostreidkov na zabezpečovanie informácií v prípravnom konaní. In ŠČERBA, Filip, ŠČERBOVÁ, Veronika (eds). Olomoucké právnické dny 2018. Sborník z XII. ročníku mezinárodní vědecké konference Olomoucké právnické dny (Sekce trestního práva) pořádané ve dnech 24.-25. 5. 2018 Právnickou fakultou Univerzity Palackého v Olomouci. 1. vydání Olomouc: Iuridicum Olomoucense, o.p.s., 2018, s. 102-122.

Tajemství cloudu odhaleno. [online]. Cloudforce.cz. 26 September 2006. [cit. 25 August 2019]. Available on <http://www.cloudforce.cz/tajemstvi-cloudu-odhaleno/>.

VALUCH, Jozef; GÁBRIŠ Tomáš; HAMULÁK, Ondrej. Cyber attacks, information attacks, and postmodern warfare. Baltic Journal of Law \& Politics, 2017, vol. 10, no. 1 , pp. 63-89.

VAN DEN HOVEN VAN GENDEREN, Robert. Privacy Limitation Clauses: Trojan Horses under the Disguise of Democracy. Wolters Kluwer, 2016. 